\title{
A Study of Angiogenesis Markers in Patients with Renal Cell Carcinoma Undergoing Therapy with Sunitinib
}

\author{
CLIVE STUBBS $^{1 *}$, ANTONIO D. BARDOLI $^{2 *}$, MEHRAN AFSHAR $^{3}$, SARAH PIRRIE $^{1}$, \\ MANUELA MISCORIA ${ }^{1}$, ISABELLA WHEELEY ${ }^{4}$ and EMILIO PORFIRI ${ }^{1,4}$ \\ ${ }^{1}$ University of Birmingham, Birmingham, U.K.; \\ ${ }^{2}$ College of Medical and Dental Sciences, University of Birmingham, Birmingham, U.K.; \\ ${ }^{3}$ Cancer Research Unit, University of Warwick, Coventry, U.K.; \\ ${ }^{4}$ Birmingham University Hospitals NHS Trust, Birmingham, U.K.
}

\begin{abstract}
Background: Sunitinib is a tyrosine kinase inhibitor (TKI) targeting tumour angiogenesis in patients with advanced renal cell carcinoma (RCC). Currently no universally agreed model exists correlating the expression of angiogenesis markers with the success of treatment. Patients and Methods: We retrospectively analysed archival tissue for 59 RCC patients treated with sunitinib. The expression of angiogenesis markers VEGF-A, VEGFR, PDGF $\beta \beta, P D G F R$, CCNDI and CA9 was assessed by immunohistochemistry (IHC) and correlated with overall survival (OS) and progression-free survival (PFS). Results: The median OS and median PFS of the whole group of patients was 24.6 months (17.3-34.2) and 19.5 months (11-27) respectively. VEGFA was positive in $29 \%$ of tumors, whereas VEGFR was expressed in only $12 \%$ of tumours. $P D G F \beta \beta$ and its receptor were detected in a minority of cases. CCND1 and CA9 were positive in $44 \%$ and $60 \%$ of cases. Conclusion: The OS and PFS achieved by our patients reflected previous observations seen with sunitinib, but no correlation was found between expression of angiogenesis markers and clinical outcome.
\end{abstract}

Angiogenesis plays a vital role in the development of renal cell carcinoma (RCC) or its histotype, clear cell renal cell carcinoma (CCRCC). Vascular endothelial growth factor (VEGF)-targeted therapies have therefore been implicated in the management of RCC and CCRCC due to their antiangiogenic effects. These therapies have also been

*These Authors contributed equally to this study.

Correspondence to: Dr. Emilio Porfiri, Cancer Centre Queen Elizabeth Hospital, Birmingham, B15 2PR, U.K. Tel: +44 7952550988,e-mail: axb568@student.bham.ac.uk

Key Words: Renal cell carcinoma, sunitinib, angiogenesis, VEGF-A, VEGFR, PDGF $\beta \beta$, PDGFR, CCND1,CA9, survival, outcome. demonstrated to improve the survival of patients with advanced kidney cancer $(1,2)$.

Angiogenesis markers have been proven valuable in the analysis of angiogenesis in tissue (2) and multiple studies have revealed that expression of angiogenesis markers is often increased in renal tumours. The majority of clear cell RCCs harbour abnormalities in the tumour suppressor gene VHL, resulting in enhanced expression of growth factors such as vascular endothelial growth factor (VEGF), platelet derived growth factor (PDGF), insulin-like growth factor 2 (IGF2) and erythropoietin via downstream induction of transcription factors of hypoxia inducible factor $1 \alpha(\mathrm{HIF} \alpha)$ (3). The constitutive over expression of these genes is thought to promote the pathophysiological development of RCC by inducing abundant vascularisation and the aberrant activation of signalling pathways leading to cell proliferation and inhibition of apoptosis.

Sunitinib is an inhibitor of several tyrosine kinases including VEGFR1, VEGFR2, VEGFR3 and PDGFR $\alpha / \beta$ (4). Several clinical trials have demonstrated that sunitinib is extremely effective against clear cell $\operatorname{RCC}(4,5)$. This drug has been shown to induce an objective response in approximately $30-40 \%$ of patients (5). Importantly treatment with sunitinib has been shown to prolong PFS.

The correlation between the aberrant expression of angiogenesis markers and response to treatment with angiogenesis inhibitors, such as sunitinib has not yet been studied in detail. It is conceivable that tumours expressing increased levels of angiogenesis markers are intrinsically dependent on enhanced angiogenesis for their growth and perhaps more sensitive to therapy with angiogenesis inhibitors (6)

Several studies have looked at the correlation between the expression of angiogenesis markers and response to TKI's. The majority of these investigated individual markers of angiogenesis and to the authors knowledge only four studies exist that investigated multiple and solely angiogenesis- 
specific molecular markers in multivariate analysis (7-10). Results from the limited data available have not been harmonious, and so this remains a domain requiring further analysis.

We studied the expression of VEGF, VEGF receptor (VEGFR), PDGF, PDGF-receptor, carbonic anhydrase 9 (CA9) and cyclin D1 (CCND1) in a series of renal cell cancer patients treated with sunitinib. We attempted to correlate the expression of these markers with response to treatment and outcome. Finding a correlation between response to treatment with sunitinib and occurrence of aberrant angiogenesis will allow for identification of subsets of patients who are more likely to benefit from this drug and to utilise healthcare resources more efficiently.

Numerous studies have suggested that aberrant VEGF expression correlates with advanced stage, high nuclear grade and increased microvascular density, however no correlation with survival has yet been described. The reduction of circulating VEGF levels has been observed in a study that evaluated the effect of anti-angiogenic agents, such as bevacizumab. Terakawa et al. (7) previously demonstrated a correlation between the expression of VEGFR and PFS, in 40 cases of RCC treated with sunitinib.

PDGF is a potent mitogen which is also implicated in tumour angiogenesis (11). Expression of PDGF during hypoxia is regulated by hypoxia inducible factor $1 \alpha$ (HIF1 $\alpha)$ and by other HIF1 $\alpha$-independent mechanisms; however its role in the development of clear-cell RCC and its prognostic significance is not yet known.

CA9is an enzyme normally up-regulated by HIF-1 during hypoxia. Increased CA9 expression was a favourable prognostic factor for patients with metastatic clear-cell RCC (12).

CCND1 has been shown to be a downstream target of HIF2 (13) and has been used to detect the activation of HIF.

\section{Patients and Methods}

Patient selection and data collection. Fifty-nine consecutive patients with advanced RCC who commenced treatment with sunitinib at Queen Elizabeth Hospital (QEH) Birmingham between July 2006 and May 2012 and whose histology specimen from tumour biopsy or nephrectomy was available were included in the analysis. Eligibility criteria for treatment with sunitinib were: histologicallyconfirmed RCC, measurable disease, adequate organ function, absence of significant co-morbidities, informed consent and the potential to derive a clinical benefit from treatment with this drug Baseline clinical characteristics including age, gender, Eastern Cooperative Oncology Group (ECOG) Performance Status, tumour histology, number of metastatic sites, date of diagnosis of renal cancer, previous systemic treatments, previous nephrectomy and laboratory test results were reviewed retrospectively. Data were collected from electronic patient record systems, clinic annotations, laboratory files, radiology files and pharmacy records. Paraffin embedded tumour samples were retrieved from the clinical diagnostic archive of the Department of Pathology, Queen Elizabeth Hospital. These were used to prepare microscope slides suitable for immunohistochemistry (IHC). This study was granted ethics approval by the South Birmingham Research Ethics Committee (08/H1207/4).

Administration of treatment. Sunitinib was administered at a dose of $50 \mathrm{mg}$ once per day in six week cycles using the standard schedule. Patients were reviewed at day 15 and day 28 during the 1 st cycle, and every 6 weeks or when clinically indicated during subsequent cycles. Treatment continued until disease progression, clinical deterioration or intolerable toxicity. Continuation of sunitinib after disease progression was permitted if, in the opinion of the attending physician, the patient could still gain clinical benefit from the treatment.

Immunohistochemistry. Assessment of expression of angiogenesis markers was carried out on the paraffin embedded tumour samples. All procedures were carried out in the Department of Pathology $(\mathrm{QEH})$ or in the laboratories of the School of Cancer Sciences University of Birmingham. The expression of 6 angiogenesis markers, VEGF-A, VEGFR-2, PDGF $\beta \beta$, PDGFR, CCND1 and CA9 were analysed immunohistochemically in the tumour tissue and in the surrounding normal renal tissue using primary antibodies described in Table I.

For each angiogenesis marker a semi-quantitative scoring system was developed to quantify its level of expression in the tumour tissue compared to the normal renal tissue. The levels of expression for each marker were assessed using a grading technique. The score ranged from 0-5 with 0 showing no expression and 5 high expression. This was further split to record 0,1 as 'Negative' and $2,3,4,5$ as 'Positive' in standard and $1 \%$ of cells graded. This scoring system was utilised to dichotomise the group into negative and positive expression, with scores of 1 being negative and all others counted as positive. This assessment was carried out by a pathologist who was blinded to outcome of treatment and patient information to minimise potential bias.

Statistical analysis. OS was calculated from the start of treatment with sunitinib to death from any cause and patients were censored at the date last known to be alive. Median OS was estimated using the Kaplan Meier method. All statistical analyses were performed using the Stata 12.1 software package.

Tumour response was assessed retrospectively according to the RECIST criteria using clinical and radiological information from the patient's notes and classified as: Complete Response (CR), Partial Response (PR), Stable Disease (SD), and Progressive Disease (PD). Response was assessed after every 3 cycles of treatment unless otherwise required clinically. Progression Free Survival (PFS) was calculated from the start of the treatment to confirmation of Progressive Disease (either radiological or clinical) or death by any cause and patients were censored at the last time known to be progression free and alive.

Initial univariate analysis using Cox proportional hazards modelling was conducted to investigate the following risk factors potentially linked to OS: gender (male $v s$. female), number of metastatic sites ( 1 vs. 2 vs. 2 or more), ECOG performance status (0 vs. 1 or more), haemoglobin level (normal vs. abnormal), grade ( 2 or less $v s .3$ or more), vascular invasion (absent vs. present), fat invasion (absent $v s$. present), Heng risk score (favourable $v s$. 
Table I. Immunohistochemistry techniques conducted on all six markers.

\begin{tabular}{|c|c|c|c|c|c|}
\hline Antigen & Unmasking method & Antibody & $\begin{array}{l}\text { Dilution incubation } \\
\text { antibody }\end{array}$ & $\begin{array}{l}\text { Secondary } \\
\text { antibody }\end{array}$ & $\begin{array}{c}\text { Evaluation of sample } \\
\text { positivity }\end{array}$ \\
\hline VEGF & $\begin{array}{l}\text { WCAP buffer } \mathrm{pH} 8 \text {; } \\
\text { bathroom thermostat } \\
98^{\circ} \mathrm{C} \text { for } 30 \text { minutes }\end{array}$ & $\begin{array}{l}\text { Monoclonal murine } \\
\text { ab1316-100 Abcam, } \\
\text { Cambridge, UK }\end{array}$ & $\begin{array}{c}\text { 1: } 1000 \text { room } \\
\text { temperature } \\
\text { environment } 60^{\circ} \mathrm{C}\end{array}$ & $\begin{array}{l}\text { Polyclonal goat anti-rabbit- } \\
\text { HRPP0448, DAKO temperature } \\
\text { environment } 30^{\circ} \mathrm{C}\end{array}$ & $\begin{array}{l}\text { Evaluated separately } \\
\text { cut-off: }>10 \%->1 \%\end{array}$ \\
\hline VEGFR & $\begin{array}{l}\text { EDTA }(1 \mathrm{mM}) \\
\text { buffer pH } 9 ; \\
65^{\circ} \mathrm{C} \text { overnight }\end{array}$ & $\begin{array}{l}\text { Rabbit polyclonal; } \\
\text { ab38473-100 Abcam, } \\
\text { Cambridge, UK }\end{array}$ & $\begin{array}{c}\text { 1:1000 overnight } \\
4^{\circ} \mathrm{C}\end{array}$ & $\begin{array}{l}\text { Polyclonal goat anti-rabbit- } \\
\text { HRPP0448, DAKO temperature } \\
\text { environment } 30^{\circ} \mathrm{C}\end{array}$ & $\begin{array}{l}\text { Cut-off: }>10 \% \text { cell }= \\
\text { moderate to high }\end{array}$ \\
\hline PDGF $\beta \beta$ & $\begin{array}{l}\text { Citrate buffer } \\
\mathrm{pH} 6 ; 98^{\circ} \mathrm{C} \text { for } \\
20 \mathrm{~min}\end{array}$ & $\begin{array}{l}\text { Rabbit polyclonal; } \\
\text { ab15499-500 Abcam, } \\
\text { Cambridge, UK }\end{array}$ & $\begin{array}{c}1: 100 \text { room } \\
\text { temperature } \\
\text { environment } 60^{\circ} \mathrm{C}\end{array}$ & $\begin{array}{l}\text { Polyclonal goat anti-rabbit- } \\
\text { HRPP0448, DAKO temperature } \\
\text { environment } 30^{\circ} \mathrm{C}\end{array}$ & $\begin{array}{l}\text { Evaluated separately } \\
\text { cut-off: }>10 \%->1 \%\end{array}$ \\
\hline PDGFR & $\begin{array}{c}\text { EDTA }(1 \mathrm{mM}) \text { buffer } \\
\mathrm{pH} 8^{\circ} \mathrm{C}-65^{\circ} \mathrm{C} \\
\text { overnight }\end{array}$ & $\begin{array}{l}\text { Rabbit monoclonal; } \\
\text { ab32570-100 Abcam, } \\
\text { Cambridge, UK }\end{array}$ & $\begin{array}{c}1: 250 \text { room } \\
\text { temperature } \\
\text { environment } 60 \%\end{array}$ & $\begin{array}{l}\text { Polyclonal goat anti-rabbit- } \\
\text { HRPP0448, DAKO temperature } \\
\text { environment } 30^{\circ} \mathrm{C}\end{array}$ & $\begin{array}{c}\text { Cut-off: }>10 \% \\
\text { cell moderate -high }\end{array}$ \\
\hline CA9 & $\begin{array}{c}\text { EDTA }(1 \mathrm{mM}) \text { buffer } \\
\mathrm{pH} 8^{\circ} \mathrm{C}-65^{\circ} \mathrm{C} \\
\text { overnight }\end{array}$ & $\begin{array}{l}\text { Rabbit monoclonal; } \\
\text { ab15086-100 Abcam, } \\
\text { Cambridge, UK }\end{array}$ & $\begin{array}{c}\text { 1: } 1000 \text { room } \\
\text { temperature } \\
\text { environment } 60^{\circ} \mathrm{C}\end{array}$ & $\begin{array}{l}\text { Polyclonal goat anti-rabbit- } \\
\text { HRPP0448, DAKO temperature } \\
\text { environment } 30^{\circ} \mathrm{C}\end{array}$ & $\begin{array}{c}\text { Cut-off: }>10 \% \\
\text { cell moderate }- \text { high }\end{array}$ \\
\hline CCND1 & $\begin{array}{c}\text { EDTA }(1 \mathrm{mM}) \text { buffer } \\
\text { pH } 8 ; 98^{\circ} \mathrm{C} \text { for } \\
20 \mathrm{~min}\end{array}$ & $\begin{array}{l}\text { Rabbit polyclonal; } \\
\text { ab25088 Abcam, } \\
\text { Cambridge, UK }\end{array}$ & $\begin{array}{c}1: 25 \text { room } \\
\text { temperature } \\
\text { environment } 60^{\circ} \mathrm{C}\end{array}$ & $\begin{array}{l}\text { Polyclonal goat anti-rabbit- } \\
\text { HRPP0448, DAKO temperature } \\
\text { environment } 30^{\circ} \mathrm{C}\end{array}$ & $\begin{array}{l}\text { Cut-off }>10 \% \\
\text { cell moderate- high }\end{array}$ \\
\hline
\end{tabular}

intermediate $v s$. poor). Following the univariate analysis, multivariate analysis using Cox proportional hazards modelling was conducted using likelihood ratio tests with significance set at 0.05 to determine factors of exclusion and inclusion within the baseline model. Once a baseline model had been constructed, which included all currently available baseline measures, each of the 6 biomarkers were then separately added to the model to investigate whether they were of prognostic value.

\section{Results}

The median age at the start of treatment was 61 years (range, 34-86 years). Cases were predominantly clear-cell types $(\mathrm{n}=50 ; 84.7 \%)$ (Table II) and in 7 cases $(11.9 \%)$ sarcomatoid component was present. Performance status at the start of sunitinib treatment was recorded as ECOG 0 in 32 cases (54.2\%), ECOG 1 in 19 cases $(32.2 \%)$ and ECOG 2 in 8 cases $(13.6 \%)$. Overall 33 patients $(55 \%)$ received sunitinib as first-line treatment, while $26(44 \%)$ had previously received other systemic therapies: twenty four $(41 \%)$ patients received IFN, one $(2 \%)$ patient received temsirolimus and one $(2 \%)$ patient received sorafenib (Table III). Of the 59 patients, 19 patients $(32.2 \%)$ achieved an objective response to treatment, 26 (44\%) had stable disease and 13 (22\%) had disease progression. Response could not be assessed in one patient. At the time of data cut off, 46 patients (78\%) had experienced disease progression. Forty-one patients had discontinued sunitinib, with $33(80 \%)$ of these due to progression.

VEGF expression was positive in $29 \%$ (cut off 10\%) and $44 \%$ (cut off $1 \%$ ) of cases, but VEGFR2 was expressed only in $12 \%$ of tumours. PDGF $\beta \beta$ and its receptor were present in

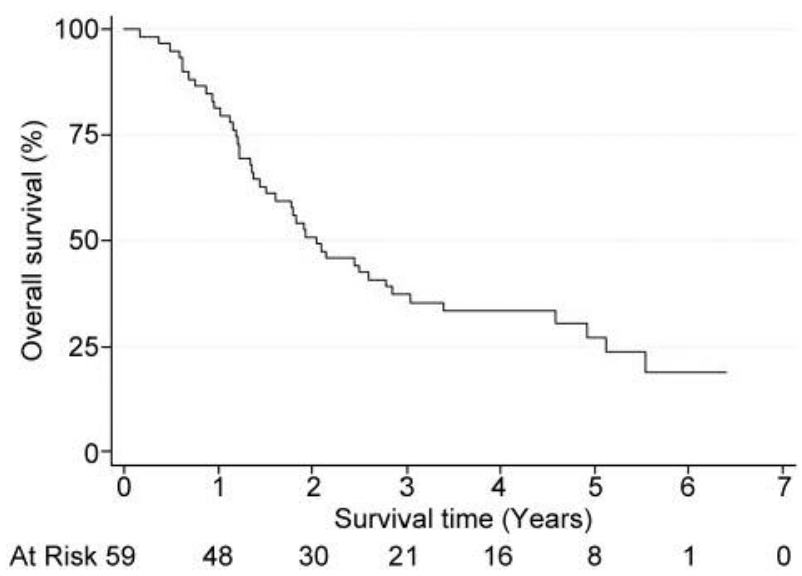

Figure 1. Kaplan Meier plot to show overall survival of patients from the start of sunitinib treatment.

only a minority of cases examined. CCND1 and CA9, instead were positive respectively in $26(44 \%)$ and $40(60 \%)$ cases.

Overall survival. Forty three $(73 \%)$ patients had died at the time of analysis. The median survival time from the start of sunitinib was 2.05 years (24.6 months) (CI 95\%; 1.44-2.85 years) (Figure 1).

Univariate analysis of factors considered for the base model for assessing OS included gender, the number of metastatic sites and haemoglobin level at start of treatment, as well as others described in Table IV. Grade, vascular invasion, fat 
Table II. Patient characteristics.

\begin{tabular}{|c|c|c|c|c|c|c|}
\hline & \multicolumn{2}{|c|}{$\begin{array}{c}\text { Alive } \\
(\mathrm{N}=16)\end{array}$} & \multicolumn{2}{|c|}{$\begin{array}{c}\text { Dead } \\
(\mathrm{N}=43)\end{array}$} & \multicolumn{2}{|c|}{$\begin{array}{l}\text { Overall } \\
(\mathrm{N}=59)\end{array}$} \\
\hline & $\mathrm{N}$ & $\%$ & $\mathrm{~N}$ & $\%$ & $\mathrm{~N}$ & $\%$ \\
\hline \multicolumn{7}{|c|}{ Vascular invasion } \\
\hline No & 7 & $58.3 \%$ & 11 & 28.9 & 18 & $36 \%$ \\
\hline Yes & 5 & $41.7 \%$ & 25 & 71.1 & 32 & $64 \%$ \\
\hline Missing & 4 & & 5 & & 9 & \\
\hline Total & 12 & $100 \%$ & 38 & $100 \%$ & 50 & $100 \%$ \\
\hline \multicolumn{7}{|c|}{$\mathrm{T}$ classification } \\
\hline 1 & 3 & $27.3 \%$ & 6 & $15.8 \%$ & 9 & $18.4 \%$ \\
\hline 2 & 1 & $9.1 \%$ & 1 & $2.6 \%$ & 2 & $4.1 \%$ \\
\hline 3 & 6 & $54.5 \%$ & 29 & $76.3 \%$ & 35 & $71.1 \%$ \\
\hline 4 & 1 & $9.1 \%$ & 2 & $5.3 \%$ & 3 & $6.1 \%$ \\
\hline Missing & 5 & & 5 & & 10 & \\
\hline Total & 11 & $100 \%$ & 38 & $100 \%$ & 49 & $100 \%$ \\
\hline \multicolumn{7}{|c|}{$\mathrm{N}$ classification } \\
\hline 0 & 4 & $80 \%$ & 14 & $77.8 \%$ & 18 & $78.3 \%$ \\
\hline 1 & 0 & $0 \%$ & 2 & $11.1 \%$ & 2 & $8.7 \%$ \\
\hline 2 & 1 & $20 \%$ & 2 & $11.1 \%$ & 3 & $13 \%$ \\
\hline Missing & 11 & & 25 & & 36 & \\
\hline Total & 5 & $100 \%$ & 18 & $100 \%$ & 23 & $100 \%$ \\
\hline \multicolumn{7}{|l|}{ Necrosis } \\
\hline No & 1 & $50 \%$ & 2 & $10 \%$ & 3 & $13.6 \%$ \\
\hline Yes & 1 & $50 \%$ & 18 & $90 \%$ & 19 & $86.4 \%$ \\
\hline Missing & 14 & & 23 & & 37 & \\
\hline Total & 2 & $100 \%$ & 20 & $100 \%$ & 22 & $100 \%$ \\
\hline \multicolumn{7}{|c|}{ Sarcomatoid component } \\
\hline No & 13 & $81.3 \%$ & 39 & $90.7 \%$ & 52 & $88.1 \%$ \\
\hline Yes & 3 & $18.8 \%$ & 4 & $9.3 \%$ & 7 & $11.9 \%$ \\
\hline Total & 16 & $100 \%$ & 43 & $100 \%$ & 59 & $100 \%$ \\
\hline
\end{tabular}

Table III. Summary of treatment characteristics.

\begin{tabular}{lc}
\hline Median age at start of sunitinib & 61 years \\
$\geq 65$ years & $22(37 \%)$ \\
Range & $34-86$ \\
Treatments pre-sunitinib & \\
IFN & $24(44 \%)$ \\
Temsirolimus & $1(2 \%)$ \\
Sorafenib & $1(2 \%)$ \\
None & $33(55 \%)$ \\
\hline
\end{tabular}

invasion and HENG score were shown to be clinically significant at the value of 0.05 and were included in the multivariate analysis of angiogenesis markers (Figure 2). The multivariate analysis showed only fat invasion to be significant and therefore was the only univariate factor adjusted for when reviewing the prognostic value of angiogenesis markers (Table $\mathrm{V}$ ). Both fat and vascular invasion are factors in determining the Tumour-NodeMetastasis (TNM) stage of the disease and we can infer that while both were independently clinically significant in the univariate analysis, if combined they would show a correlation
Table IV. Univariate base model for overall survival.

\begin{tabular}{|c|c|c|c|c|c|}
\hline Variable & $\beta$ & Standard error & $\mathrm{HR}$ & $p$-value & $90 \% \mathrm{CI}$ \\
\hline \multicolumn{6}{|l|}{$\mathrm{M} / \mathrm{F}$} \\
\hline Male & Reference & Reference & 1 & 0.471 & Reference \\
\hline Female & 0.252 & 0.35 & 1.287 & & 2.290 \\
\hline \multicolumn{6}{|l|}{ Grade } \\
\hline 2 or less & Reference & Reference & 1 & 0.041 & Reference \\
\hline 3 or more & 0.757 & 0.370 & 2.132 & & 3.917 \\
\hline \multicolumn{6}{|c|}{ Vascular invasion } \\
\hline Absent & Reference & Reference & 1 & 0.050 & Reference \\
\hline Present & 0.720 & 0.367 & 2.054 & & 3.756 \\
\hline \multicolumn{6}{|l|}{ Fat Invasion } \\
\hline Absent & Reference & Reference & 1 & 0.028 & Reference \\
\hline Present & 0.860 & 0.390 & 2.363 & & 4.491 \\
\hline \multicolumn{6}{|c|}{ ECOG Perfomance } \\
\hline Absent & Reference & Reference & 1 & 0.108 & Reference \\
\hline Present & 0.493 & 0.307 & 1.638 & & 2.713 \\
\hline \multicolumn{6}{|l|}{ Heng risk score } \\
\hline Favourable & Reference & Reference & 1 & 0.044 & Reference \\
\hline Intermediate & 0.553 & 0.450 & 1.738 & & 3.647 \\
\hline Poor & 1.381 & 0.550 & 3.981 & & 9.837 \\
\hline \multicolumn{6}{|l|}{$\begin{array}{l}\text { Number of } \\
\text { metastatic sites }\end{array}$} \\
\hline 1 & Reference & Reference & 1 & 0.343 & Reference \\
\hline 2 & 0.535 & 0.374 & 1.738 & & 3.156 \\
\hline More than 2 & 0.216 & 0.402 & 1.241 & & 2.404 \\
\hline \multicolumn{6}{|l|}{ Haemoglobin } \\
\hline Normal & Reference & Reference & 1 & 0.354 & Reference \\
\hline Abnormal & 0.294 & 0.317 & 1.340 & & 2.259 \\
\hline
\end{tabular}

Table V. Multivariate analysis of angiogenesis markers adjusted for fat invasion of overall survival.

\begin{tabular}{|c|c|c|c|c|c|}
\hline Adjusted for & Variable & Standard error & - HR & $p$-Value & $95 \%$ C.I \\
\hline \multirow[t]{15}{*}{ Fat invasion } & VEGF $1 \%$ & & & & \\
\hline & Negative & Reference & 1 & 0.550 & Reference \\
\hline & Positive & 0.316 & 1.207 & & 2.242 \\
\hline & VEGF $10 \%$ & & & & \\
\hline & Negative & Reference & 1 & 0.378 & Reference \\
\hline & Positive & 0.341 & 1.351 & & 0.692 \\
\hline & CA9 & & & & \\
\hline & Negative & Reference & 1 & 0.057 & Reference \\
\hline & Positive & 0.326 & 0.538 & & 1.019 \\
\hline & PDGFR1 & & & & \\
\hline & Negative & Reference & 1 & 0.442 & Reference \\
\hline & Positive & 0.365 & 0.756 & & 1.019 \\
\hline & CYD1 & & & & \\
\hline & Negative & Reference & 1 & 0.205 & Reference \\
\hline & Positive & 0.366 & 1.590 & & 3.256 \\
\hline
\end{tabular}

together. Within the Fat Invasion adjusted model, none of the angiogenesis markers met the 0.05 significance level.

The involvement of CA9 was borderline significant within the model, whilst no other marker was able to infer any difference. 


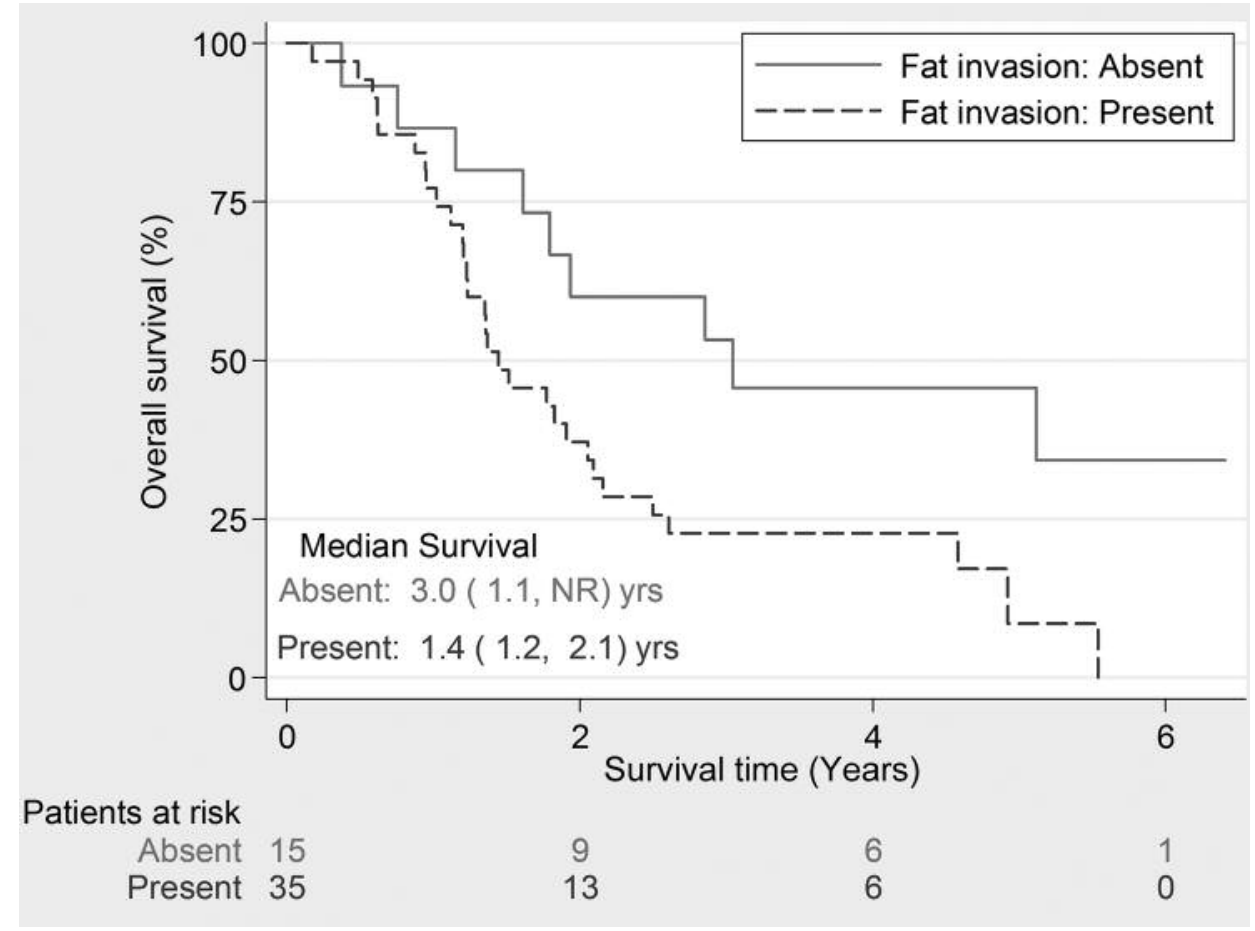

Figure 2. Kaplan-Meier plot to show Overall Survival split by Fat Invasion ( $p=0.028)$.

PDGF $\beta \beta$ and PDGFR were both expressed in only a few cases and did not infer any prognostic potential. Until the full pathway and direct/ indirect interactions between the various proteins has been fully interpreted, the role and use of PDGF $\beta \beta$ and PDGFR in RCC will need to be finalised. Similarly, CCND1 whilst being scored as present in $40 \%$ of cases did not show any correlation with PFS. It is possible that other factors may influence its expression.

Progression-free survival. In total 47 (80\%) patients had progressed or died at the time of analysis. The median PFS time was 1.63 years $(95 \% \mathrm{CI}=0.92-2.27)$, which is longer than the 11 months reported in the literature (10). The Kaplan-Meier plot is presented in Figure 3. Univariate analysis of factors considered in the Base Model for assessing PFS included the same eight baseline characteristics as included in the model for OS.

In the univariate analysis the baseline characteristics that met the 0.05 significance level were vascular invasion and fat invasion. The multivariate analysis only showed fat invasion to be significant and therefore was the only univariate factor adjusted for when reviewing the angiogenesis markers as prognostic factors. This data is shown in Table VI. In results similar to overall survival the multivariate analysis showed that none of the angiogenesis markers met the 0.05 level of significance after being adjusted for fat invasion. Again, CA9 was the nearest to achieving the level of significance in the PFS model.

\section{Discussion}

Sunitinib has demonstrated significant improvements in objective responses and PFS in metastatic RCC $(14,15)$. Despite that targeted drugs are designed to selectively inactivate a protein, or group of proteins, within a specific intracellular signalling pathway, the cascade of events affected by inactivation of one or more of the proteins within the pathway has not yet been completely elucidated and thus highlights the complexity of the pathway and the impact of other biological, clinical or tumour related factors that are present in vivo and possibly absent in vitro.

Biological, clinical or tumour related factors could be inherent compensation mechanisms and cause subtle differences between interactions of receptors or activation of alternative pathways of angiogenesis that are developed by cancer cells (which could be a possible effect of developing inherent resistance to targeted agents) (16). Alongside the molecular and genetic characteristics of the tumour the patient's clinical condition and histopathology may also have an impact on the response to anti-angiogenesis therapies (17). 
Table VI. Multivariate analysis of angiogenesis markers adjusted for fat invasion of progression free survival.

\begin{tabular}{|c|c|c|c|c|c|c|c|}
\hline Adjusted for & Variable & $\beta$ & Standard error & HR & $p$-Value & HR & 95\% C.I \\
\hline \multirow[t]{15}{*}{ Fat invasion } & VEGF 1\% & & & & & & \\
\hline & Negative & Reference & Category & 1 & 0.560 & Reference & Category \\
\hline & Positive & 0.178 & 0.305 & 1.195 & & & 2.174 \\
\hline & VEGF $10 \%$ & & & & & & \\
\hline & Negative & Reference & Category & 1 & 0.856 & Reference & Category \\
\hline & Positive & 0.061 & 0.334 & 1.062 & & 0.552 & 2.044 \\
\hline & CA9 & & & & & & \\
\hline & Negative & Reference & Category & 1 & 0.138 & Reference & Category \\
\hline & Positive & -0.460 & 0.310 & 0.631 & & 0.344 & 1.160 \\
\hline & PDGFR $1 \%$ & & & & & & \\
\hline & Negative & Reference & Category & 1 & 0.750 & Reference & Category \\
\hline & Positive & -0.110 & 0.345 & 0.896 & & 0.455 & 1.763 \\
\hline & CYD1 & & & & & & \\
\hline & Negative & Reference & Category & 1 & 0.994 & Reference & Category \\
\hline & Positive & 0.002 & 0.327 & 1.002 & & 0.528 & 1.901 \\
\hline
\end{tabular}

The study of markers able to predict the response of RCC to the treatments has so far failed to produce robust results that can be confidently applied to a clinical setting. Patient selection is currently based on clinical criteria (MSKCC or Heng prognostic scores); patients within the favourable or intermediate prognosis groups are candidates for treatment with drugs targeting VEGF signalling (Sunitinib, Sorafenib, Pazopanib) $(18,19)$, while patients with poor prognosis may receive mTOR inhibitors (Temsirolimus) or best supportive care (10).

In our study we analysed the expression of different markers within the complex process of angiogenesis and we evaluated its relationship with the outcomes to treatment with sunitinib. None of the markers we analysed proved to be an independent predictor of OS or PFS. To the group's knowledge we are the first to attempt to use PDGF $\beta \beta$ and its associated receptor in such an assay. However, interesting results have emerged for CA9 although sample size was not sufficient to achieve a 0.05 level of significance. Compared to all the other factors included within the analysis, CA9 showed a statistically significant difference within the statistical model for being present or absent and impact on OS.

Interestingly several established prognostic factors such as performance status, haemoglobin and hengs score were not shown to be prognostic in our cohort of patients. Both the retrospective nature of this study and the small number of patient s may account partly for this unexpected finding. Another interesting finding is the sole prognostic value of fat invasion in this cohort of patients. Although fat invasion is part of the TNM staging for RCC, it is unclear why it would prognosticate so strongly in a cohort of metastatic RCC patients. This is particularly difficult to explain given that fat

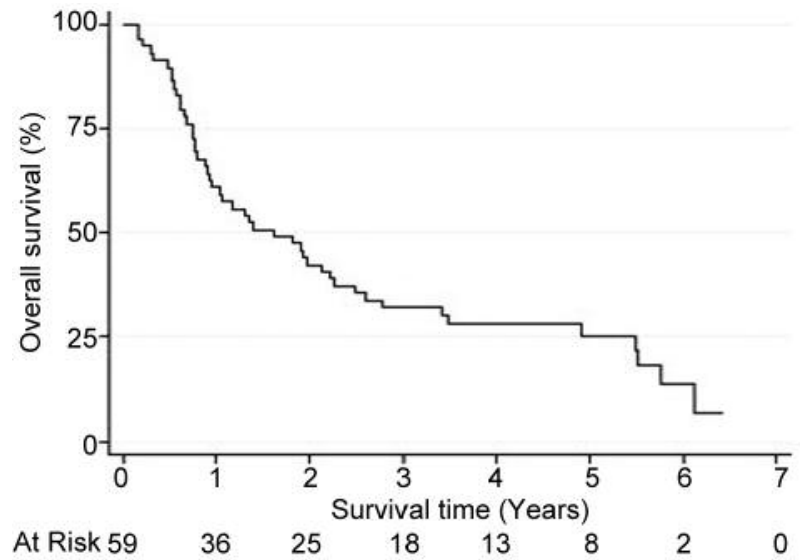

Figure 3. Kaplan-Meier plot to show PFS from the start of sunitinib treatment.

invasion was the only factor linked to survival in the group of factors examined.

Our study was limited by its relatively small cohort size, which we believe may be a contributory factor leading to an inability to obtain levels of statistical significance for our findings. It is also important to note that several studies when conducting IHC staining on prepared slides (in an assay similar to those described in our methods) used a semiquantitative scoring system of absent/weak/strong. Maybe the further elucidation of a five tiered scoring system has sub-divided the relatively small sample size and proved to be a limitation to the data analysis and that of a more simple approach (one reflected in Leibovich et al. and Skapa et al.) would yield more interesting results $(12,20)$. 
The current literature shows very little progress with work being carried out on angiogenesis markers as predictive factors for RCC, although some show VEGF (19) (and its associated receptor) and CA9 (20) as important factors within the process of angiogenesis $(7,9)$. Although not statistically significant the data presented here highlight the need for future studies to be conducted on the angiogenesis pathway and to identify new targets for providing better information for treatment selection and prognostic modelling. The results from our data follow the literature and show CA9 and VEGF $(19,20)$ as possible targets for further work.

\section{References}

1 Lampinem AM, Virman JP, Bono P, Luukkaala TH, Sunela KL, Kujala PM, Saharinen P and Kellokumpu-Lehtinen PI: Novel angiogenesis markers as long term prognostic factors in patients with renal cell cancer. Clin Genitourin Cancer, 2016. doi: 10.1016/j.clgc.2016.07.008. [Epub ahead of print]

2 Kim HL, Seligson D, Liu X, Janzen N, Bui MH, Yu H, Shi T, Belldegrun AS, Horvath $\mathrm{S}$ and Figlin RA: Using tumor markers to predict the survival of patients with metastatic renal cell carcinoma. J Urol 173(5): 1496-1501, 2005.

3 Na X, Wu G, Ryan CK, Schoen SR, di'Santagnese PA and Messing EM: Overproduction of vascular endothelial growth factor related to von Hippel-Lindau tumor suppressor gene mutations and hypoxia-inducible factor- 1 alpha expression in renal cell carcinomas. J Urol 170(2 Pt1): 588-592, 2003.

4 Coppin C PF, Kumpf J, Coldman A and Wilt T: Immunotherapy for advanced renal cell cancer. Cochrane Database Syst Rev 3: 1-46, 2004.

5 Bukowski RM, Elsen T, Szczylik C, Stadler WM, Simantov R, Shan M, Elting J, Pena C and Escudier B: Final results of the randomized phase III trial of sorafenib in advanced renal cell carcinoma: Survival and biomarker analysis. J Clin Oncol 25(18S): 90180, 2007.

6 Dirix LY, Vermeulen PB and Pawinski A: Elevated levels of the angiogenic cytokines basic fibroblast growth factor and vascular endothelial growth factor in sera of cancer patients. Br J Cancer 76(2): 238-244, 1997.

7 Terakawa T, Miyake H, Kusuda Y and Fujisawa M: Expression level of vascular endothelial growth factor receptor-2 in radical nephrectomy specimens as a prognostic predictor in patients with metastatic renal cell carcinoma treated with sunitinib. Urol Oncol 31(4): 493-498, 2013.

8 Garcia-Donas J, Leandro-García LJ, González Del Alba A, Morente M, Alemany I and Esteban E: Prospective study assessing hypoxia-related proteins as markers for the outcome of treatment with sunitinib in advanced clear-cell renal cell carcinoma Ann Oncol 24(9): 2409-2414, 2013.
9 You D, Song SH, Cho YM, Lee JL, Jeong IG and Song C: Predictive role of tissue-based molecular markers in patients treated with sunitinib for metastatic renal cell carcinoma. World J Urol 33: 111-118, 2014.

10 Patel PH, Senico PL, Curiel RE and Motzer RJ: Phase I study combining treatment with temsirolimus and sunitinib malate in patients with advanced renal cell carcinoma. Clin Genitourin Cancer Jan 7(1): 24-27, 2009.

$11 \mathrm{Yu} \mathrm{J}$, Ustach C and Kim H-RC: Platelet-derived growth factor signaling and human cancer: J Biochem Mol Biol 36(1): 49-59, 2003.

12 Leibovich BC, Sheinin Y and Lohse CM: Carbonic anhydrase IX is not an independent predictor of outcome for patients with clear cell renal cell carcinoma. J Clin Oncol 25(30): 4757-4764, 2007.

13 Zatyka M, da Silva NF and Clifford SC: Identification of Cyclin D1 and Other Novel Targets for the von Hippel-Lindau Tumor Suppressor Gene by Expression Array Analysis and Investigation of Cyclin D1 Genotype as a Modifier in von Hippel-Lindau Disease. Cancer Res 62(13): 3803-3811, 2002.

14 Yilmazer D, Han U and Onal B: A comparison of the vascular density of VEGF expression with microvascular density determined with CD34 and CD31 staining and conventional prognostic markers in renal cell carcinoma. Int Urol Nephrol 39(3): 691-698, 2007.

15 Cella D, Li JZ and Cappelleri JC: Quality of life in patients with metastatic renal cell carcinoma treated with sunitinib or interferon alfa: results from a phase III randomized trial. J Clin Oncol 26(22): 3763-3769, 2008.

16 Hicklin DJ and Ellis LM: Role of the vascular endothelial growth factor pathway in tumor growth and angiogenesis. J Clin Oncol 23(5): 1011-1027, 2005.

17 Croom KF and Perry CM: Imatinib mesylate: in the treatment of gastrointestinal stromal tumours. Drugs 63(5): 513-522; discussion 23-24, 2003.

18 Minardi D, Lucarini G, Santoni M, Mazzucchelli R, Burattini L and Pistelli M: VEGF expression and response to sunitinib in patients with metastatic clear cell renal cell carcinoma. Anticancer Res 33(11): 5017-5022, 2013.

19 Deprimo SE, Bello CL and Smeraglia J: Circulating protein biomarkers of pharmacodynamic activity of sunitinib in patients with metastatic renal cell carcinoma: modulation of VEGF and VEGF-related proteins. J Transl Med 5: 32, 2007.

20 Skapa P, Hyrsl L, Zavada J, Soukup J and Zamecnik J: Carbonic anhydrase IX expression in clear cell renal cell carcinomas negatively correlates with the proportion of the granular cell component. J Clin Oncol 26(22): 3809-3811; author reply 3811$382,2008$.
Received October 30, 2016

Revised November 27, 2016

Accepted December 9, 2016 